\title{
ОРГАНИЗАЦИЯ ОХРАННОЙ ЗОНЫ И КОНСЕРВАЦИОННЫЕ РАБОТЫ НА ГОРОДИЩЕ ДЖАНКЕНТ
}

\section{(C) 2020 г. А. А. Тажекеев, Р. Т. Дарменов, Ж. К. Султанжанов}

В статье изложены результаты работ по сохранению и музеефикации средневекового городища Джанкент в низовьях Сырдарьи. Городище Джанкент является одним из ключевых памятников при изучении истории средневековых огузов. Данный памятник с 2005 г. исследуется Джанкентской археологической экспедицией. В его изучении применяются методы археологических и междисциплинарных исследований. С 2014 г. наряду с археологическими раскопками ведутся также работы по организации охранной зоны и мероприятия по консервации. Результаты этих работ показывают свою эффективность, демонстрируя хорошую сохранность архитектурных конструкций городища. На наш взгляд, продолжение консервационных работ будет способствовать созданию археологического парка на территории городища Джанкент.

Ключевые слова: археология, низовья р. Сырдарьи, городище Джанкент, средневековье, музеефикация, охранная зона, реконструкция, консервация

\section{Введение}

Городище Джанкент расположено в 1,5 км к югу от села Жанкент (Казалинский р-н, Кызылординская обл.), в низовьях р. Сырдарьи. Городище имеет форму, близкую к прямоугольной, общая площадь составляет около 16 га. Оно обведено стенами с встроенными в них башнями, выступающими полукругом с внешней стороны стен. Фортификационные сооружения возведены из пахсовых блоков. Хорошо сохранилась восточная стена, в середине которой находятся ворота с двумя выносными башнями. На топографическом плане городища, отснятом Б. В. Андриановым и Н. И. Игониным в 1963 г. [Аржанцева, Рузанова, 2010, рис. 9], обозначено углубление, возможно указывающее на местонахождение западных ворот. Как видно на аэрофотоснимках, город делится центральной улицей на две равные части. По обе стороны улицы расположен «шахристан», в северозападной части городища находится цитадель размерами $110 \times 110$ м (рис. 1). Современные исследователи Джанкента, основываясь на типологии городищ Г. В. Шишкиной и О. Н. Иневаткиной, отнесли Джанкент к типу I.2 «город, укрепленный цитаделью в черте городской ограды» [Аржанцева и др., 2014, с. 293].

Первые археологические исследования на памятнике были проведены П. И. Лерхом. В 1867 г. по поручению Императорской Археологической комиссии П. И. Лерх и его помощник М. К. Приоров посетили городище Джанкент. Они описали памятник и провели съемку местности. В отчете П. И. Лерх отметил, что еще до его прибытия городище было нарушено киргизами, которые исполь- 
Тажекеев А.А., Дарменов Р.Т., Султанжанов Ж.К. Организация охранной зоны и консервационные работы на городище Джанкент
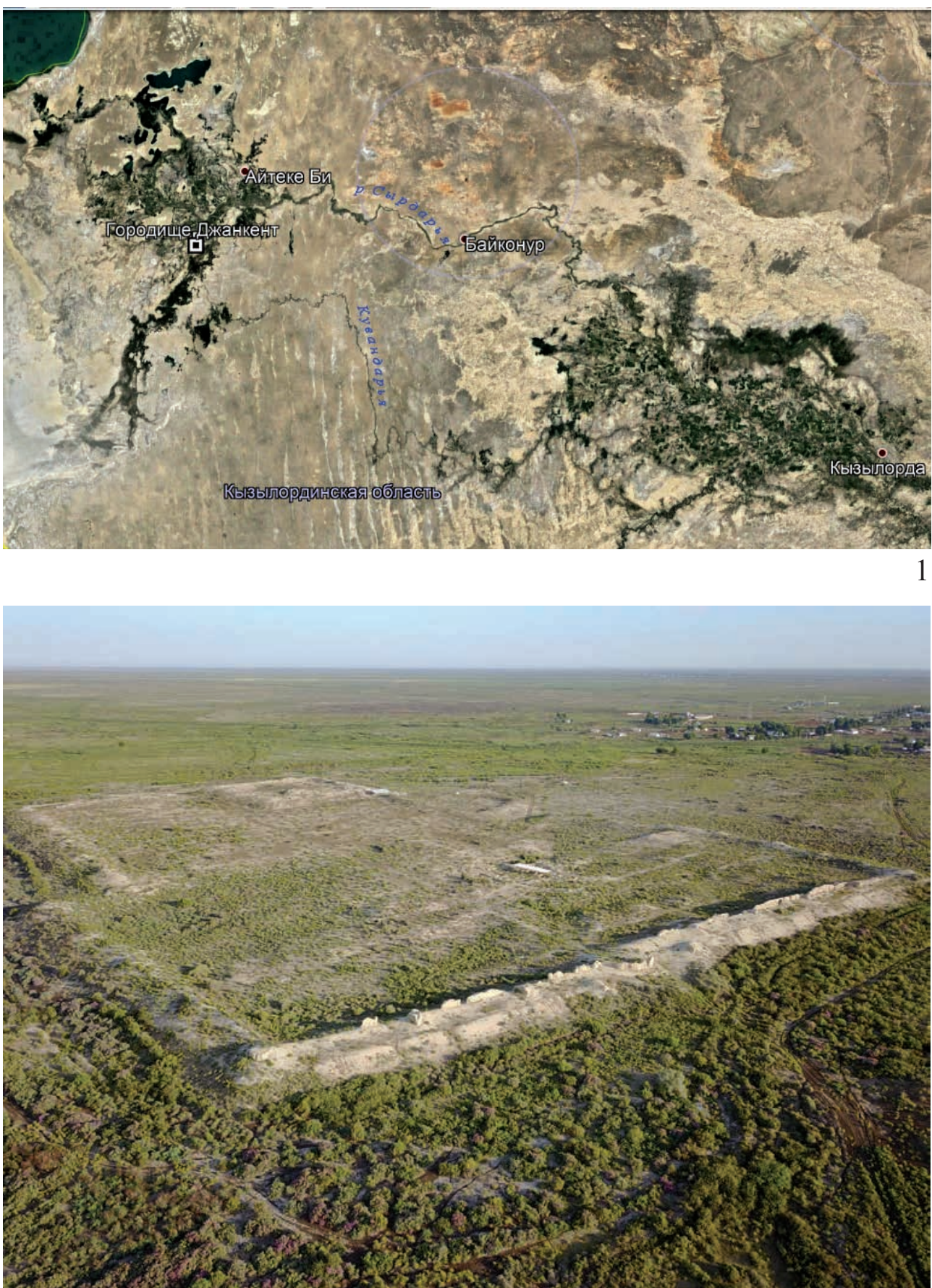

Рис. 1. Городище Джанкент. 1 - расположение памятника на карте Кызылординской области; 2 - общий вид памятника с востока. Фото авторов

Fig. 1. The medieval town of Jankent. 1 - The location of the site on a map of the Kyzylorda region; 2-General view of the site from the east. Authors's photos 
зовали квадратные кирпичи с памятника для своих могил. П. И. Лерхом были раскопаны четыре объекта в центральной и западной части городища. Он пришел к заключению, что памятник представляет собой остатки городища Янгикент, упоминаемого в средневековых письменных источниках [Лерх, 1870, с. I-VII].

Осенью 1946 г. авиаразведочный отряд Хорезмской археологоэтнографической экспедиции (ХАЭЭ) исследовал территорию Янгикентской группы памятников, в которую входят города Кескен-куюк кала, Джанкент, Куюк кала [Толстов, 1947, с. 57-70]. В результате работ экспедиции было сделано описание городища Джанкент, произведена аэрофотосъемка и собран подъемный материал.

В итоге С. П. Толстов, руководитель ХАЭЭ, ввел в научный оборот термин «болотные городища». Эта группа памятников, по его мнению, располагается: «...неподалеку от Казалинска на плоской, низменной, влажной равнине, ограниченной на севере Сыр-Дарьей, на западе Аральским морем и на востоке - полосой болот и камышовых плавней, которыми заканчивается староречье Куван-Дарьи» [Толстов, 1962, с. 276]. Именно эту территорию С. П. Толстов считал исконным районом обитания огузов.

На основании подъемного материала городище Джанкент было датировано С. П. Толстовым периодом с начала нашей эры до X-XI вв. [Толстов, 1947, с. 68]. Позже Л. М. Левина, анализируя керамические материалы «болотных городищ», пришла к выводу, что в Джанкенте есть также керамика развитого средневековья [Левина, 1971, с. 77].

ХАЭЭ проводила полевые исследования на территории Джанкента только в 1946 и 1963 гг., хотя сама экспедиция просуществовала до 1997 г. Археологические работы на городище Джанкент были возобновлены после принятия государственной программы «Культурное наследие» и проведения конференции по археологии Приаралья в 2004 г. (г. Кызылорда). На конференции было заключено сотрудничество исследователей Казахстана и России. В 2011 г. в рамках соглашения между Кызылординским и Тюбингенским (Германия) университетами к экспедиции присоединились сотрудники Тюбингенского университета.

\section{Исследовательские работь}

С 2005 г. в течение 14 полевых сезонов (с небольшими перерывами в 2008 и 2010 гг.) стационарные археологические работы на городище ведет Жанкентская/Джанкентская археологическая экспедиция (ЖАЭ) ${ }^{1}$. [Аржанцева и др., 2010; Комплексные исследования..., 2014; Султанжанов, 2018]. К настоящему времени исследовано более 1500 кв.м памятника. Основные полевые работы проводятся на участке жилого квартала в восточной и западной частях городища (раскопы № 1 и 8); в месте стыка северо-восточного угла цитадели с северной оборонительной стеной (раскоп № 2); на месте восточных ворот (раскоп № 7). Проведен комплекс почвенных, геофизических и геоморфологических исследований. Начаты планомерные работы по изучению керамического комплекса и комплекса костей животных. За весь период работ ЖАЭ опубликовано два сводных отчета $(2010 ; 2011)$ по работам на городище Джанкент, издана книгаальбом «Цивилизации, затерянные в песках» (2013) и сборник «Комплексное исследование городища Джанкент: работы 2011-2014 гг.» (2014). 
Тажекеев А.А., Дарменов Р.Т., Султанжанов Ж.К. Организация охранной зоны и консервационные работы на городище Джанкент

Результаты этих исследований ежегодно освещаются в материалах научных конференций разного уровня и в научных журналах.

Наряду с комплексными археологическими исследованиями на памятнике проводятся организация охранной зоны и консервационные работы.

Организащия охранной зонь памятника. В 2014 г. состоялась 32 сессия Кызылординского областного маслихата, посвященная проблеме охраны и использования историкокультурных памятников Кызылординской области. На заседании вынесено решение об утверждении границы охранной зоны, зоны регулирования застройки и охраняемо- го природного ландшафта городища Джанкент [Решение..., 2014]. К решению прикреплены два приложения. Решение осуществлено на основе Закона Республики Казахстан «Об охране и использовании объектов историко-культурного наследия» от 02.07.1992 г.

В границы охраняемой исторической зоны Джанкента вошли следующие памятники: городище Джанкент, могильник Мынтобе и безымянный средневековый мавзолей. Общая площадь охранной зоны составила 45 га, площадь регулирования зон застройки - 75 га, площадь зоны охраняемого природного ландшафта 237 га (рис. 2).

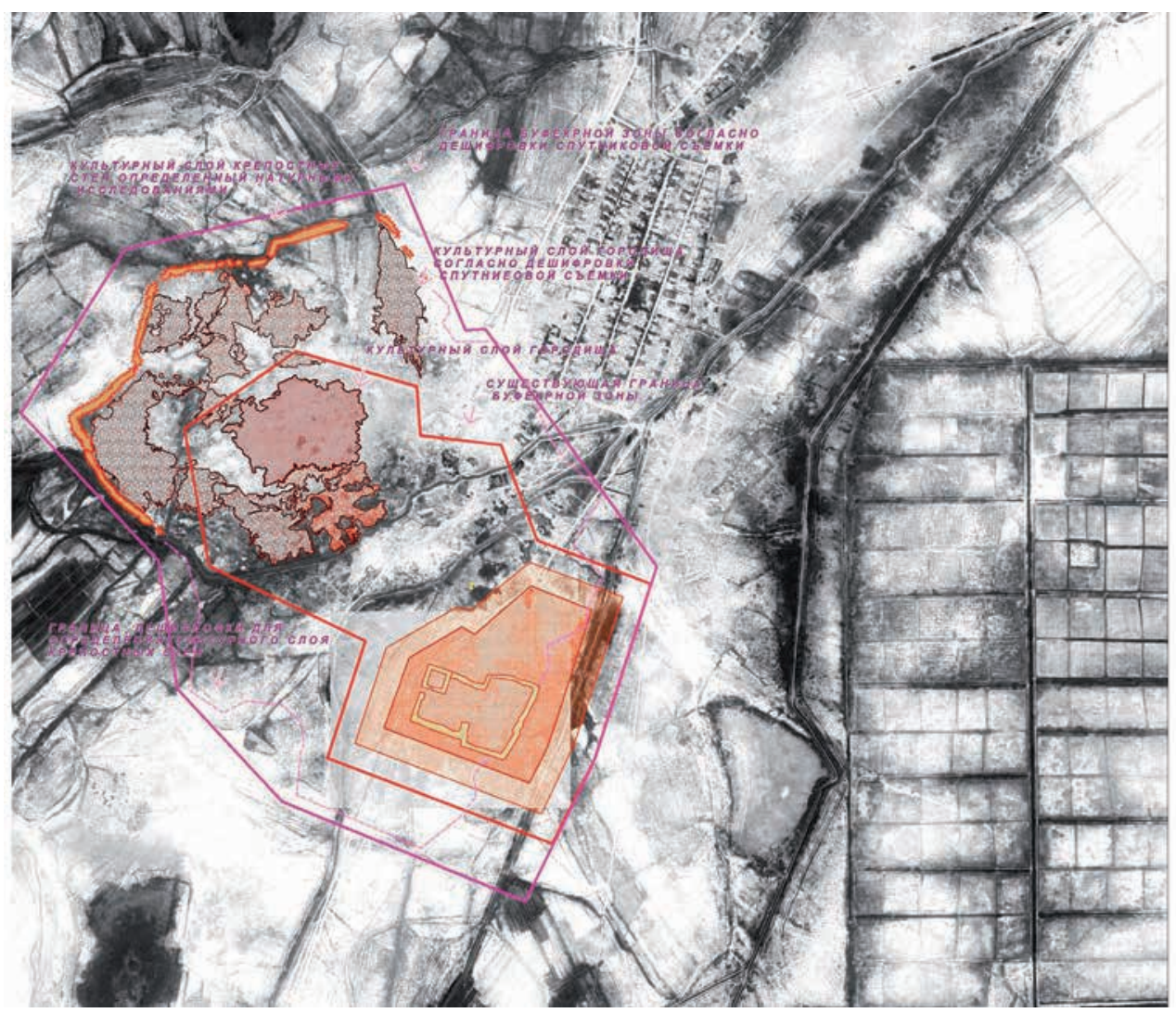

Рис. 2. Охранная зона городища Джанкент (автор плана Казпроектреставрация)

Fig. 2. The conservation zone of Jankent (author of the plan Kazproject restoration) 
Консервационные работы. В 2016 г. члены научно-практического совета «По охране памятников истории и культуры Кызылординской области, управления культуры, архивов и документации Кызылординской области» при ГКУ проанализировали состояние археологического памятника Джанкент. В составе комиссии были М. Елеуов, А. А. Тажекеев, А. Сайлау, С. Козейбаев и сотрудники государственного учреждения «По охране памятников истории и культуры Кызылординской области». Они установили, что несколько объектов, раскопанных на городище Джанкент, подвергаются разрушительному увлажнению в осенне-зимнее время и нуждаются в срочной консервации. Объекты пострадали от процессов эрозии, таких как воздействие дождей, циркуляция дождевой воды и ее скопление внутри остатков сооруже- ний, фактор промерзания, фитофактор и антропогенный фактор.

Основываясь на этих выводах и предложенных рекомендациях по консервации, в 2016-2019 гг. после археологических исследований нами были осуществлены работы на двух объектах:

1. Раскоп № 1 - Жилищнохозяйственный комплекс в восточной части городища. В данное время на раскопе № 1 выявлено три строительных периода, открыты и изучены более 60 жилых помещений. Среди них помещения № 1-10 были реконструированы. Стены помещения были приподняты на 4-5 рядов сырцовых кирпичей, также стены, суфы, центральные очаги этих помещений были отштукатурены саманной массой. Были изготовлены копии очажных подставок и тандыров помещений (рис. 3-4).

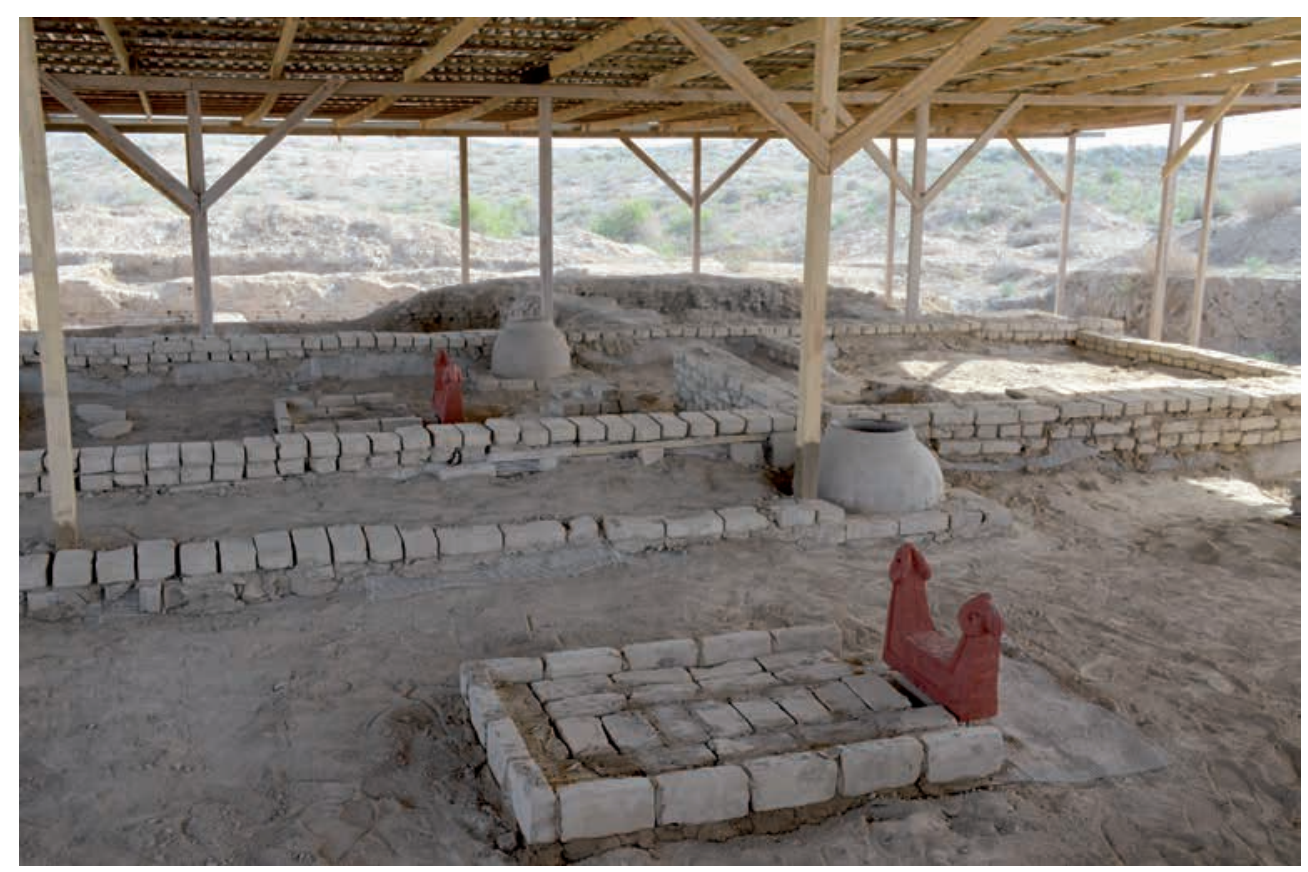

Рис. 3. Реконструкция сырияовых конструкиий на раскопе № 1

Fig. 3. Reconstruction of structures at excavation No. 1 
Тажекеев А.А., Дарменов Р.Т., Султанжанов Ж.К. Организация охранной зоны и консервационные работы на городище Джанкент

2. Раскоп № 2 - Оборонительные башни северной обводной стены цитадели городища. В полевом сезоне 2012, 2016 и 2018 гг. были открыты три полукруглые башни диаметром 7 м. Участок между башнями составляет 16 м. В ходе консервационных работ башни были заполнены грунтом и оштукатурены саманной массой (рис. 5).

В целом, нами были предложены конкретные меры по консервации и реставрации археологических объектов, включающие:

- зачистку и дренаж прилегающего к объектам пространства;

- обеспечение регулярного оттока атмосферных осадков;

- реставрацию основания стен (заполнение швов между кирпичами);

- восстановление утраченных частей конструкций и оштукатуривание их поверхностей.
В качестве материалов для реставрации были выбраны источники местного строительного сырья. Вокруг Джанкента имеются глинистые почвы, оттенок которых варьирует от светлого до темно-красного, а состав отличается уровнем содержания солей. Есть также пески различного качества. Разнообразие ресурсов предоставляет массу возможностей для добротной консервации. Предварительные испытания почв, залегающих возле памятника, показали, что не все они подходят для консервации вследствие засоленности. При высыхании обмазки, выполненной из такой почвы, появляются трещины, и она отделяется от стены.

$$
\text { Сырцовые (саманные) отло- }
$$
жения из завалов внешней стены, лежавшие более трех лет под открытым небом и подвергающиеся воздействию щелочной дождевой воды,

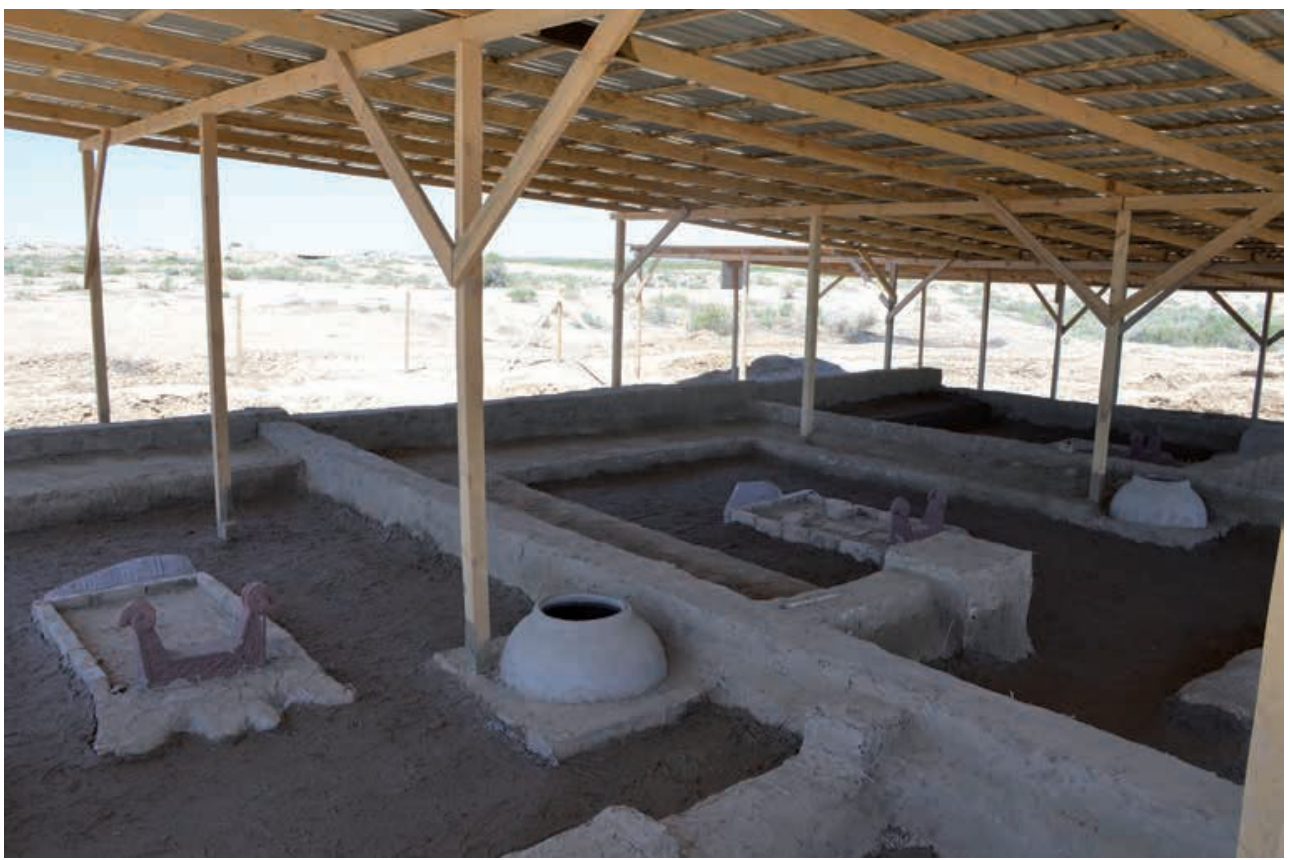

Рис. 4. Раскоп № 1. Вид помещений после оштукатуривания

Fig. 4. Excavation No. 1. View of premises after plastering 


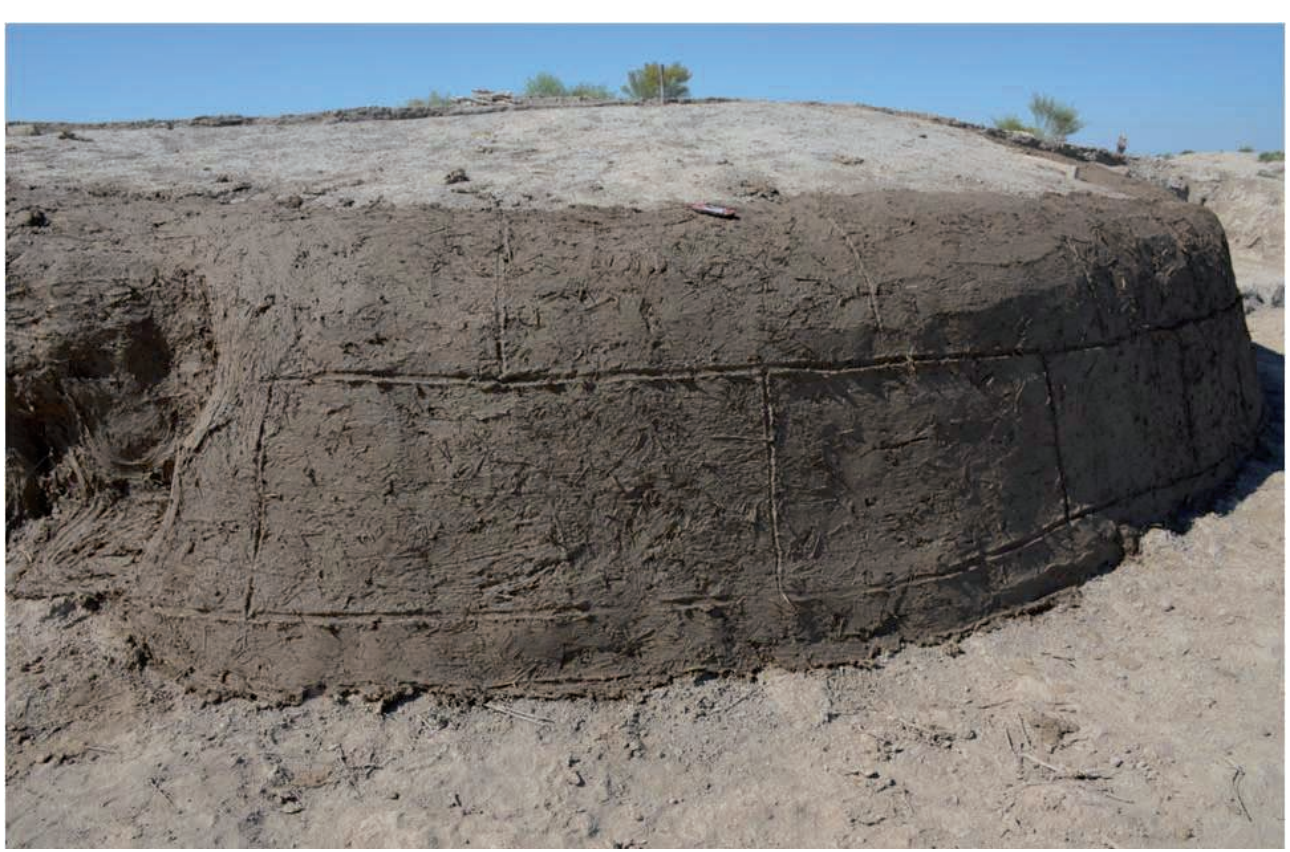

Рис. 5. Раскоп № 2. Вид башни после оштукатуривания

Fig. 5. Excavation No. 2. View of the tower after plastering

дают самый низкий показатель растрескивания. Такая глина обладает наилучшими качествами скрепления и цементирования. Из этого сырья сотрудниками экспедиции изготавливался саман (местный строительный раствор из глины с примесью измельчённого камыша).

Саман был использован для консервации башен северной обводной стены. Опытным путем была определена рецептура самана. Сначала в глину примеси не добавлялись, в результате на штукатурке было много трещин, и она плохо связывалась с основой. Состав строительного раствора был улучшен путем добавления песка и большого количества измельченного камыша (не измельченный камыш после усыхания глины распрямлялся и разрывал штукатурку).

Над постройками жилищнохозяйственного комплекса на раскопе № 1 был возведен навес с отдельным водостоком. Экспериментальная конструкция из дерева и металла навеса охватила площадь около 250 кв. м (рис. 6). Надо отметить, что расширение площади раскопа № 1 с каждым полевым сезоном, способствует возведению новых участков навеса и увеличению его размера.

\section{Заключение}

Таким образом, комплексный подход, применямый в последнее десятилетие при исследовании городища Джанкент, обнаруживает свою эффективность. Постепенно проясняется сложная структура этого памятника, этапы его формирования, время его функционирования и запустения. Результаты консервационных работ показывают хорошую сохранность сырцовых сооружений.

В дальнейшие задачи экспедиции входят проблемы изучения внутренней планировки и жилых кварталов в западной части городища, 
Тажекеев А.А., Дарменов Р.Т., Султанжанов Ж.К. Организация охранной зоны и консервационные работы на городище Джанкент

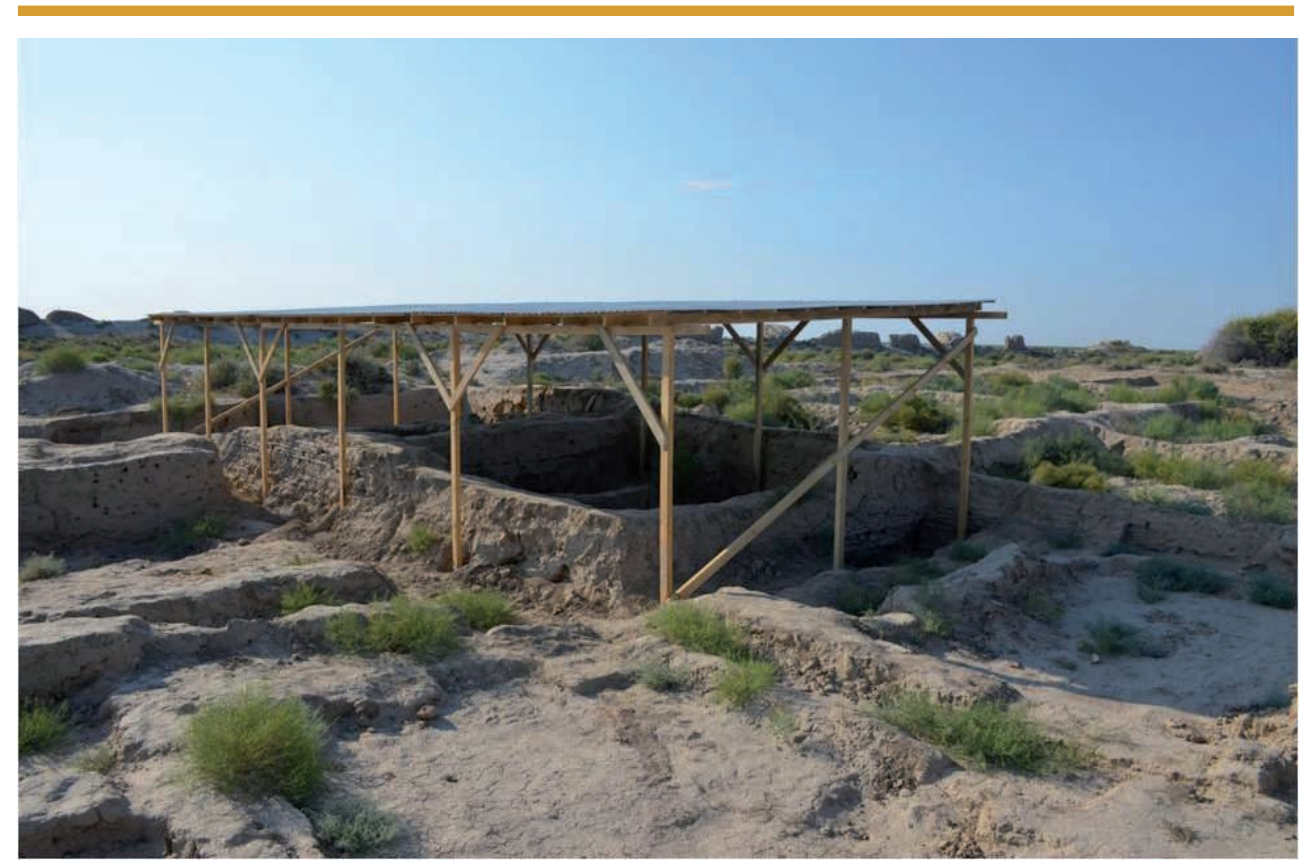

Pис. 6. Раскоп № 1. Навес

Fig. 6. Excavation No. 1. Canopy

нижних строительных горизонтов и структуры ворот памятника, также работы по музеефикации вскрытых объектов. В будущем продолжение ра- бот в этом направлении будет способствовать созданию археологического парка на территории памятника.

\section{Примечание}

1 - В составе экспедиции в разные годы участвуют следующие сотрудники: А. А. Тажекеев (руководитель казахстанской группы), Ж. Т. Сыдыкова, С. У. Билалов, Г. Т. Амиргалина, Р. Т. Дарменов, И. С. Курманиязов, К. Шарапова, Ж. К. Султанжанов, И. А. Аржанцева (руководитель российской группы), С. А. Рузанова, Э. Д. Зиливинская, Г. Харке; геофизики И. Н. Модин, С. А. Ерохин; почвоведы А. Е. Иванова, М. А. Бронникова; реставратор Е. А. Пшеничнова; художник А. Ж. Назаров; архитектор Т. Ю. Черезова; палеозоолог Л. Л. Гайдученко и др.

\section{ЛИТЕРАТУРА}

1. Аржаниева И.А., Зиливинская Э.Д., Караманова М.С., Рузанова С.А., Уткельбаев К.З., Сыдыкова Ж.Т., Билалов С.У. Сводный отчет об археологических работах на городище Джанкент в 2005-2007, 2009 гг. Кызылорда: «Компас Кызылорда», 2010. 162 с.

2. Аржанцева И.А., Рузанова С.А. Городище Джанкент и проблема «болотных городищ» // Древние цивилизации на Среднем Востоке. Археология, история, культура: матер. междунар. науч. конф., посвящ. 80-летию Г.В. Шишкиной. М.: Государственый музей Востока, 2010. С. 11-13.

3. Аржанцева И.А., Харке Г., Тажекеев А.А. Итоги и перспективы изучения городища Джанкент. Проблемы интерпретации полученных материалов // Комплексные исследования городища Джанкент (работы 2011-2014 гг.). Алматы: «Арыс», 2014. С. 293-295. 
4. Комплексные исследования городища Джанкент (работы 2011-2014 гг.). Алматы: Издательство «Арыс», 2014. 320 с.

5. Левина Л.М. Керамика Нижней и Средней Сырдарьи в I тысячелетии н.э. / ТХАЭЭ. М.: Наука, 1971. Т. VII. 263 с.

6. Лерх П.И. Археологическая поездка в Туркестанский край в 1867 г. // Отчет ИАК. СПб.: Типография ИАН, 1870. С. I-X.

7. Решение Кызылординского областного маслихата от 21.11.2014 г. № 233. Об утверждении границы охранной зоны, зоны регулирования застройки и зона охраняемого природного ландшафта памятника истории и культуры «Городище Жанкент», расположенного в Казалинском районе. URL: http://adilet.zan.kz/rus/docs/ V14L0004817 (дата обращения: 27.11.2019).

8. Султанжанов Ж.К. Комплексные исследования на городище Джанкент // Актуальная археология 4. Комплексные исследования в археологии: матер. Междунар. науч. конф. молодых ученых (г. Санкт-Петербург, 2-5 апреля 2018 г.). СПб.: ИИМК PAH, 2018. C. 272-274.

9. Толстов С.П. Города гузов // СЭ. 1947. № 3. С. 55-102.

10. Толстов С.П. По древним дельтам Окса и Яксарта. М.: Восточная литература, 1962. 323 c.

\title{
Сведения об авторах:
}

Тажекеев Азилхан Ауезханович - кандидат исторических наук, руководитель НИЦ «Археология и этнография», Кызылординский государстенный университет им. Коркыт Ата (г. Кызылорда, Казахстан), azik8484@mail.ru

Дарменов Рустем Турарбекович - ведущий научный сотрудник, Национальный музей РК (г. Нур-Султан, Казахстан), darmenov_rustem@mail.ru

Султанжанов Жетесби Канапияевич - докторант, Тюбингенский университет Эберхарда-Карла (г. Тюбинген, Германия), zhetesbi.sultanzhanov@mail.ru

\section{ЖАНКЕНТ ҚАЛАШЫҒЫНДАҒЫ ҚОРҒАУ АЙМАҒЫН ҰЙЫМДАСТЫРУ ЖӘНЕ ТҰМШАЛАУ ЖҰМЫСТАРЫ}

\author{
Ә. Ә. Тәжекеев, Р. Т. Дарменов, Ж. К. Султанжанов
}

Мақалада Сырдария өзенінің төменгі ағысында орналасқан ортағасырлық Жанкент қалашығында жүргізілген қорғау және музеефикация жұмыстарының нәтижелері көрсетіледі. Жанкент қалашығы оғыз тайпаларының тарихын зерттеуде тірек ескерткіштердің бірі болып табылады. Бұл ескерткіш 2005 жылдан бастап Жанкент археологиялық экспедициясының мүшелерімен зерттеліп жатыр. Оның зерттелуінде археологиялық және пәнаралық зерттеу әдістері қолданылады. 2014 жылдан бастап археологиялық қазбамен қатар қалашықтың қорғау аймағын ұйымдастыру және консервациялық сипаттағы жұмыстар жүргізілуде. Бұл жұмыстардың нәтижесінде Жанкенттің архитектуралық ғимараттарының жақсы сақталғандығын байқаймыз. Біздің пікірімізше, қайта-қалпына келтіру және тұмшалау жұмыстарын жалғастыру Жанкент қалашығының аумағында археологиялық саябақ құруға ықпал етеді.

Түйін сөздер: археология, Сырдария өзенінің төменгі ағысы, Жанкент қалашығы, орта ғасыр, музеефикация, қорғау аймағы, қайта қалпына келтіру, тұмшалау

\section{ORGANIZATION OF CONSERVATION ZONE AND CONSERVATION WORKS ON JANKENT}

\section{A. A. Tazhekeyev, R. T. Darmenov, Zh. K. Sultanzhanov}

This article presents the results of the conservation and museumification of the medieval town of Jankent in the lower Syrdarya. The Jankent is one of the key sites in the study of the history of medieval Oghuzes. Since 2005, this site has been explored by the Jankent 
Тажекеев А.А., Дарменов Р.T., Султанжанов Ж.К. Организация охранной зоны и консервационные работы на городище Джанкент

Archaeological Expedition. Its research uses archaeological and interdisciplinary research methods. Since 2014, along with archaeological excavations, work is underway to organize a conservation zone and conservation work. The results of these works show their effectiveness, showing the good preservation of the domestic architectural building of the town. In our opinion, the continuation of conservation work will contribute to the creation of an archaeological park on the territory of Jankent.

Keywords: archaeology, lower reaches of the Syrdarya, Jankent, middle ages, museumification, conservation zone, reconstruction, conservation

\section{REFERENCES}

1. Arzhantseva, I. A., Zilivinskaya, E. D., Karamanova, M. S., Ruzanova, S. A., Utkelbayev, K. Z., Sydykova, Zh. T., Bilalov, S. U. 2010. Svodnyy otchet ob arkheologicheskikh rabotakh na gorodishche Dzhankent v 2005-2007, $2009 \mathrm{gg}$ (Consolidated report on archaeological work to the town of Dzhankent in 2005-2007, 2009). Kyzylorda: Compass-Kyzylorda Publ. (in Russian).

2. Arzhantseva, I. A., Ruzanova, S. A. 2010. In Materialy mezhdunarodnoy nauchnoy konferentsii, posvyashchennoy 80-letiyu G.V. Shishkinoy (Materials of the international scientific conference dedicated to the 80th anniversary of G.V. Shishkina). Moscow: State Museum of the East Publ., 11-13 (in Russian).

3. Arzhantseva, I. A., Kharke, G., Tazhekeyev, A. A. 2014. In Kompleksnyye issledovaniya gorodishcha Dzhankent (raboty 2011-2014 gg.) (Comprehensive studies of the Dzhankent town (works 2011-2014)). Almaty: Arys Publ., 293-295 (in Russian).

4. In Kompleksnyye issledovaniya gorodishcha Dzhankent (raboty 2011-2014 gg.) (Comprehensive studies of the Dzhankent town (works 2011-2014)). Almaty: Arys Publ., 320 (in Russian).

5. Levina, L. M. 1971. Keramika Nizhney i Sredney Syrdarii v 1 tysyacheletii n.e. (The Pottery of the Lower and Middle Syrdarya in the 1st millennium AD) (in Russian).

6. Lerkh, P. I. 1870. In Otchet IAK (Report of the Imperial Archaeological Commission). Saint Petersburg: Imperial Academy of Sciences Publ., I - X (in Russian).

7. Decision of the Kyzylorda regional maslikhat dated November 21, 2014 No. 233. URL: http://adilet.zan.kz/rus/docs/V14L0004817 (in Russian).

8. Sultanzhanov, Zh. K. 2018. In Materialy Mezhdunarodnoy nauchnoy konferentsii molodykh uchenykh (Materials of the International Scientific Conference of Young Scientists). Saint Petersburg: Institute of History and Material Culture of the RAS Publ., 272-274 (in Russian). Russian).

9. Tolstov S. P. 1947. In Sovetskaya Etnografiya (Soviet ethnography), 3, 55-102 (in

10. Tolstov S. P. 1962. In Po drevnim deltam Oksa i Yaksarta (According to the ancient deltas of Oks and Yaksart). Moscow: Eastern literature Publ. (in Russian).

\section{About the Authors:}

Tazhekeyev Azilkhan A. Candidate of historical sciences, director, research center "Archeology and Ethnography”, Korkyt Ata Kyzylorda State University, Kyzylorda, Kazakhstan; azik8484@mail.ru

Darmenov Rustem T. Leading Researcher, National Museum of the Republic of Kazakhstan, Nur-Sultan, Kazakhstan; darmenov_rustem@mail.ru

Sultanzhanov Zhetesbi K., PhD doctoral student, Eberhard-Karl University of Tübingen, Tübingen, Germany; zhetesbi.sultanzhanov@mail.ru

\footnotetext{
Мүдделер қақтығысы туралы ақпаратты ашу. Авторлар мүдделер қақтығысының жоқтығын мәлімдейді.

/ Раскрытие информации о конфликте интересов. Авторы заявляют об отсутствии конфликта интересов.

Disclosure of conflict of interest information. The authors claims no conflict of interest.

Мақала туралы ақпарат / Информация о статье / Information about the article.

Редакцияға түсті / Поступила в редакцию / Entered the editorial office: 27.11.2019.

Рецензенттер мақұлдаған / Одобрено рецензентами / Approved by reviewers: 04.12.2019.

Жариялауға қабылданды / Принята к публикации / Accepted for publication: 11.12.2019.
} 